\title{
Caring Values and the Value of Care: Women, Maternalism and Caring Work in the Czech Republic
}

\author{
Rosie Read \\ Bournemouth University, Faculty of Health and Social Sciences, R105 Royal London House, Christchurch House, \\ Bournemouth, BH1 3LT, UK \\ rread@bournemouth.ac.uk
}

\begin{abstract}
This article examines maternalism in the Czech Republic by exploring how waged and unwaged forms of caring work were framed through discourses of women's innately caring nature in the late twentieth century. Present-day hospital volunteering programmes, which bring female, lay volunteers onto hospital wards to provide unwaged care to patients, are inscribed by maternalist tropes historically associated with domestic work and family care, rather than the neutral expertise associated with female waged care workers in public, institutional settings. The article assesses the contemporary reinvention of maternalist discourses and their capacity to mobilise unwaged caring labour.
\end{abstract}

For much of the twentieth century the right of mothers to public resources and recognition for the care they provide was enshrined within redistributive systems of both liberal capitalist and state socialist European nation states. In many cases these rights and provisions for mothers were a result of the successes of earlier nineteenth-century campaigns of bourgeois and working-class women for greater social and economic protections for mothers and children. ${ }^{1}$ Founded on the view that women were naturally suited to care giving, these maternalist forms of entitlement became embedded within the burgeoning welfare bureaucracies of the twentieth century, affording a minimum level of security for women and their children, whilst also sustaining and naturalising a highly gendered division of caring labour in industrial societies. Yet by the late twentieth century a clear shift away from these policies had become discernible, as governments of advanced economies in Europe and beyond adopted measures encouraging increased labour market participation amongst women generally, and mothers particularly. Mothers' entitlement to public resources has been eclipsed by a resurgent emphasis on women as workers. This has been championed across a broad range of political constituencies, from feminist campaigns for gender equality in employment, to neoliberal policy agendas aiming to reduce 'welfare dependency' amongst certain groups of women, notably poor single mothers. ${ }^{2}$

\footnotetext{
1 Seth Koven and Sonya Michel, 'Womanly Duties: Maternalist Politics and the Origins of Welfare States in France, Germany, Great Britain, and the United States, 1880-1920', American Historical Review, 95, 4 (1990), 1076-1108; Rebecca J. Plant and Marian van der Klein, 'Introduction: A New Generation of Scholars on Maternalism', in Marian van der Klein, Rebecca J. Plant, Nicole Sanders and Lori R. Weintrob, eds., Maternalism Reconsidered. Motherhood, Welfare and Social Policy in the Twentieth Century, (Oxford: Berghahn, 2012), 1-21.

2 Catherine Kingfisher, 'Part 1: The Big Picture: Globalization, Neoliberalism and the Feminization of Poverty', in Catherine Kingfisher, ed., Western Welfare in Decline: Globalization and Women's Poverty. (Philadelphia: University of Pennsylvania Press, 2002), 3-61. Catherine Kingfisher, A Policy Travelogue. Tracing Welfare Reform in Aotearoa/New Zealand and Canada (Oxford: Berghahn, 2013). Ann Shola Orloff, 'From Maternalism to Employment for All. State Policies to Promote Women's Employment across the Affluent Democracies', in Jonah, D. Levy, ed., The State After Statism. New State Activities in the Age of Liberalization (London: Harvard University Press, 2006), 230-68.

(C) Cambridge University Press 2019. This is an Open Access article, distributed under the terms of the Creative Commons Attribution licence (http://creativecommons.org/licenses/by/4.0/), which permits unrestricted re-use, distribution, and reproduction in any medium, provided the original work is properly cited.
} 
This transformation, which has seen a sharp decline in public funding for full-time motherhood and housewifery across much of Europe and beyond, has been called a 'farewell to maternalism' by Ann Shola Orloff. ${ }^{3}$ Yet just as mothers' entitlement to public resources qua mothers is on the wane in economically developed economies, feminist scholars have highlighted the concurrent reinvention of discourses proclaiming the vital social importance of maternal care. Recent studies have explored contemporary 'neoliberal maternalisms' - varieties of women's activism honouring motherhood in a manner entirely compatible with neoliberal imperatives to cut mothers' public entitlement and encourage instead their economic self-sufficiency through waged work. ${ }^{4}$ Of course, the coexistence of moral imperatives for mothers to both work for a living and nurture their children is not unique to the neoliberal present. Maternalist ideologies, defined by Koven and Michel as those which 'exulted women's capacity to mother and extended to society as a whole the values of care, nurturance and morality', have historically accommodated themselves to the need of most women for paid work, and at times co-existed with initiatives supporting women's employment. As I argue in this article, a more particular feature of present day maternalist ideologies is the absence of associated demands for care providers' entitlement to public resources.

I explore maternalist discourses in post-Second World War Czechoslovakia. ${ }^{6}$ Here, as elsewhere in socialist Eastern Europe, women's more or less compulsory employment was framed in terms of a political commitment to their emancipation. Women's levels of participation in the labour market rose rapidly after the Second World War, remaining high through the socialist period and after its collapse in 1989. Yet despite this ostensible commitment to gender equality, popular and official discourses asserting women's care giving as grounded in nature and biology advanced from the 1960s onwards, becoming embedded rationales for maternalist redistributive policies in the mid- to late socialist period and continuing relatively unchallenged after socialism. I argue that Czech maternalist narratives operated as powerful commentaries not only about mothers and children, but also about public care services in the socialist and post-socialist periods, particularly those delivered in residential, public institutions. Proponents of maternalist policies galvanised wider public concerns about the inadequacies of institutional care at particular historical moments during and after socialism by presenting care within the home as a self-evidently more humane, natural alternative. Care in both public/institutional and private/household settings was provided largely by women, yet only unwaged care has been maternalised through its persistent association with women's biologically given caring nature. Although conventionally associated with the private spaces of kinship or friendship networks, I argue that this unwaged, maternalised care is mobilised as a public activity by contemporary Czech hospital volunteer programmes, which bring largely female, volunteer caregivers into the public institutional space of hospitals, to supplement the care of waged professionals.

Hospital volunteering programmes first emerged in the Czech Republic during the 1990s as civil society initiatives aimed at the humanisation of health care, bringing lay volunteers onto wards to provide company and care to hospitalised patients. Most volunteers are women and the experience of volunteering is mediated through maternalist narratives about women's innately caring capacities. In order to cast such narratives into sharp relief, I contrast the unwaged care of volunteers with that of waged Czech nurses, who inhabit a highly feminised, caring profession which nevertheless sits firmly outside the purview of Czech maternalist discourse. Overall I contend that in the Czech context, maternalist narratives provide a means of supporting, generating and legitimising unwaged forms of care, which have supplemented public services at various historical junctures but which, in the case of hospital volunteering, do not raise concomitant demands for extensive public resource.

\footnotetext{
3 Orloff, 'Maternalism to Employment', 230.

4 Emily, R. Cummins and Linda M. Blum, 'Suits to Self-Sufficiency: Dress for Success and Neoliberal Maternalism', Gender and Society, 29, 5 (2015), 623-46. See also Melinda Vandenbeld Giles, 'Introduction. An Alternative Mother-Centered Economic Paradigm', in Melinda Vandenbeld Giles, ed., Mothering in the Age of Neoliberalism (Bradford, Ontario: Demeter Press, 2014), 1-19. Cited in Kingfisher, Policy Travelogue, 139-78.

5 Koven and Michel, 'Womanly', 1079.

6 Czechoslovakia was dissolved into the Czech Republic and Slovakia on 1 January 1993.
} 
This feature marks the rupture of contemporary Czech maternalist volunteering with historical antecedents in the Czech and wider European context, which unambiguously foregrounded women's entitlement to material support in order to carry out their maternal duties. Like other neoliberal maternalisms, Czech hospital volunteering does not challenge the marked reluctance on the part of governments to invest public resources in care.

My investigation draws on primary and secondary sources. My analysis of hospital volunteering is based on data gathered as part of ethnographic field research I conducted in 2008. This project examined volunteering programmes in health care settings in three urban locations - Prague, Ústí-nad-Labem and Ostrava - and entailed participant observation and over fifty semi-structured interviews with volunteers, nurses, volunteer coordinators, NGOs and hospital managers across all three sites. Almost all interviews were conducted in Czech and all translations to English are my own. My research findings have resulted from inductive, thematic analysis of my interviews and field notes, as well as newspapers, pamphlets, annual reports and other grey literature on hospital volunteering in limited circulation. My discussion of maternalist social policies and public health and care services and professions of the socialist and post-socialist periods is drawn from published academic research (in Czech and English) as well as a popular Czech fiction film. I develop my argument in sections, beginning with a discussion of contrasting forms of care work during the socialist period. First I examine how Czech nursing as gendered care work was encompassed within the socialist project of modernising health care. Moving then to a consideration of care within private, family settings, I explore how these were increasingly identified with maternalist discourses and policies in the mid- to late socialist period, and set in contrast to the inadequacies of care delivered in institutions by professionals. I then examine the emergence of hospital volunteering in the 1990s. Whilst this activity is usually presented by advocates as an expression of post-socialist civil society, I argue that it can as well be seen as a transformed variant of Czech maternalism.

\section{Nursing, Public Care and Socialist Modernity}

In socialist Czechoslovakia, the provision of universally accessible, free modern health care was seen by the country's leaders as integral to socialist modernity and economic development. Science and medical research were perceived to be crucial to producing a healthier and more productive population. ${ }^{8}$ From 1948 onwards the government strengthened centralised control over existing health insurance schemes and services and initiated a period of major state investment in health infrastructure and professions. The modernisation of nursing was one strand of these developments. Prior to this point, nursing had been poorly paid and undertaken by lower-class women with varied education and professional training. A significant proportion of nurses were nuns, working in hospitals owned and run by religious orders. ${ }^{9}$ The post-war socialist government standardised nursing training, delivering it through specialist vocational high schools for students between the ages of fourteen and nineteen. ${ }^{10}$ The curricula comprised courses in languages, history and natural sciences, specialist courses in surgery, gynaecology, microbiology (amongst others) and placements within hospitals and health care centres. Nursing was also radically secularised, with religious orders officially barred from practice. Throughout the socialist period nursing remained a female dominated occupation, widely regarded as appropriate work for women and quite unsuitable for men. Yet, nursing care was not framed as

\footnotetext{
7 Cummins and Blum, 'Suits'. See also Kingfisher, 'The Big Picture' and Orloff, 'Maternalism to Employment'.

8 Rosie Read, 'Images of Care, Boundaries of the State: Volunteering and Civil Society in Czech Health Care', Social Analysis. The International Journal of Cultural and Social Practice, 58, 3, (2014), 90-106. See also Tomasz Inglot, Welfare States in East Central Europe, 1919-2004 (Cambridge: Cambridge University Press, 2008) and Zdeněk Štich, Health Care in Czechoslovakia (Prague: Orbis, 1954).

9 Elizabeth D. Vickers, 'Frances Elisabeth Crowell and the Politics of Nursing in Czechoslovakia after the First World War', Nursing History Review: Official Journal of The American Association for the History of Nursing, 7, (1999), 67-96.

10 Valerie Todhová and Gabriela Sedláková, Nursing Education in the Czech Republic, Nurse Education Today, 28, 1 (2008), 33-8.
} 
compassionate care for which women were innately suited, but rather as the practice of scientific expertise. In contrast to Western Europe and North America, where empathy and kindness are usually seen as inherent to nursing, ${ }^{11}$ in the Czech context these qualities have not been formally valued or recognised as intrinsic to modern professional nursing practice to the same extent.

This is well illustrated in Karel Kachyňa's fiction film Nurses (Sestřičky). Released in 1983, the film is set in a Czech rural region in the early 1950s during the period of agricultural collectivisation. The story centres around two nurses: Maria, who is young and recently qualified, and her colleague, an older nurse she refers to affectionately as 'Babi' (or 'Grannie'). Maria has been reluctantly transferred to work in this backwater as punishment for an illicit sexual encounter with a male patient in her former place of work. Rural life is introduced to the viewer as Maria sees it when she arrives in the village: dirty, backward, primitive and lacking in modern facilities. On conducting a visit to the school, Maria finds that the school teacher is a drunkard and often absent from work, whilst the children are poorly clothed, unwashed and infected with lice and parasites. Many regularly miss school classes to help adults with agricultural work. As the more experienced nurse, Babi is passionately dedicated to the improvement of health conditions in the area, and she slowly convinces the initially doubtful Maria to remain a nurse in the village. Babi is a forceful character who battles daily with the intransigence of local people about health matters. She sternly reminds collective farm leaders of their legal obligations to provide appropriate washing facilities to women working in the dairy, and to allow pregnant women time off for health reasons.

Maria and Babi embody nursing as a modernising project of the socialist state. In one scene, for instance, the women visit the household of peasant farmers whose land and animals have been incorporated into a collective farm. The old male head of the household, bitter at the loss of his property, identifies the nurses with the state and greets their presence with hostility. He refuses to visit the hospital, spitting on a letter requiring him to attend a medical examination, even though he has early symptoms of tuberculosis and a baby grandchild living in the same household. Babi chastises him for hanging on to a backward way of life, criticises the unhygienic state of the house and the inadequate family care of the baby and departs with a threat that if the old man does not attend the hospital voluntarily she will 'send someone' to take him there by force.

Produced during the 1980s, Sestřičky affirms official state messages about the benefits of socialist modernisation to rural areas, ${ }^{12}$ as well as the qualities of a 'good nurse'. Maria and Babi conscientiously wield official authority to improve people's health by educating and disciplining a rural population caricatured as ignorant and irrational. Notwithstanding the frequent sexualisation of nurses, in this officially sanctioned depiction the value of nursing inheres in the practice of scientifically based expertise, rather than in compassion grounded in female nature or biology.

This fictionalised image of nursing has parallels in empirical research. In a study of Czech nursing in the 1980s, Heitlinger found that emotional skills were not given official value or recognition. Nurses were expected to embody clinical detachment, expertise and authority in their dealings with patients. They 'learned practically nothing about empathy and communication with patients, or about independent nursing judgements'. Instead 'clinical practice emphasised routine care (such as feeding,

11 Nicky James, 'Emotional Labour: Skill and Work in the Social Regulation of Feelings', The Sociological Review, 37, 1, (1989), 15-42; Nicky James, 'Care = Organisation + Physical Labour + Emotional Labour', Sociology of Health and Illness, 14, 9 (1992), 488-509; Geertje Boschma, 'Ambivalence about Nursing's Expertise: The Role of a Gendered Holistic Ideology in Nursing 1890-1990', in Anne-Marie Rafferty, Jane Robinson and Ruth Elkan, eds., Nursing History and the Politics of Welfare, (London: Routledge, 1997), 164-76; Sharon Bolton, 'Who Cares? Offering Emotion as a Gift in the Nursing Labour Process', Journal of Advanced Nursing, 32, 3, (2000), 580-6; Sharon Bolton, 'Changing Faces. Nurses as Emotional Jugglers', Sociology of Health and Illness, 23, 1 (2001), 85-100; Ellen, D. Baer, 'Do Trained Nurses . . . Work for Love, or Do They Work for Money?' Nursing and Altruism in Twenty-First Century', Nursing Historical Review, 17 (2009), 28-46; Cecilia Benoit and Alena Heitlinger, 'Women's Health Care Work in Comparative Perspective: Canada, Sweden and Czechoslovakia/Czech Republic as Case Examples', Social Science and Medicine, 47, 8 (1998), 1101-11.

12 See Paulina Bren, The Greengrocer and his TV: The Culture of Communism After the 1968 Prague Spring (Ithaca, New York: Cornell University Press, 2012). 
bathing or skin care of patients) and the correct performance of specific procedures (such as taking temperature or blood pressure, administering medication and changing dressings)'. ${ }^{13}$ More recent research on Czech nursing conducted in the late $1990 \mathrm{~s}^{14}$ and the $2000 \mathrm{~s}^{15}$ affirms the continued salience of these ways recognising and valuing nursing, even as nurses' working conditions and organisational context have been significantly altered by health service reforms and increased professional training requirements. This research suggests that Czech nursing continues to embody two state socialist legacies: health modernisation and women's emancipation through participation in waged labour and equality with men as workers. ${ }^{16}$ It has been suggested that the non-normalisation of compassionate practices indicates the inadequacies of Czech nursing during socialism. ${ }^{17}$ But this is to overlook the feminist significance of decisively decoupling nursing care from the presumption of an innately female caring nature grounded in biology, and framing the profession in terms of women's expertise as independent waged workers. Nonetheless, notions of women's innate capacity for care have been salient in other areas of social life in contemporary Czech history, as the next section explores.

\section{Women, Family Care and Maternalism}

Like nursing, household care for family members (child care, elder care, domestic work) has historically been cast as 'women's work' in the Czech context. Yet within government policies and popular discourses, women's relation to this form of unwaged work has been constituted differently to that of waged caring labour such as nursing. Since the 1960s social and family policies have helped reinforce popular essentialist narratives of women's innate ability and desire to nurture others.

In the early socialist period of the 1950s and early 1960s, women's emancipation was prioritised. Women gained new legal rights (including divorce, abortion, contraception and property) and entered the workforce in accelerated numbers as public child care facilities for children pre-school age expanded. ${ }^{18}$ Yet despite various initiatives aimed at socialising domestic work, the main priority for the socialist government was getting women into paid employment, rather than resolving the gendered division of reproductive work within families and households. A consequence of this was a decline in the post-war birth rate. ${ }^{19}$

By the 1960s a more conservative, pronatalist, maternalist gender politics emerged within official government statements and policies. ${ }^{20}$ This was prompted by official alarm about population decline, alongside doubts about the 'economic efficiency' of full-time employment for all working-age women. A series of pronatalist social policies were approved, aimed at boosting the birth rate by augmenting family and tax benefits. Public disillusion with the failure of reform communism after 1968 is often associated with the growth of widely shared cultural perceptions of the family as a site of refuge and passive resistance against an intrusive state. Yet in seeking to quell the public defiance associated

13 Alena Heitlinger, 'Czech Nursing During and After Communism', in Vittorio Olgiati, Louis H. Orzack and Mike Saks, eds., Professions, Identity and Order in Comparative Perspective (Oňati: International Institute of the Sociology of Law, 1998), 123-48. Quote on 128.

14 See Rosie Read, 'Labour and Love: Competing Constructions of 'Care' in a Czech Nursing Home', Critique of Anthropology, 27, 2 (2007), 203-22 as well as Read, 'Images'.

15 Ema Hrešanová, 'Nobody in a Maternity Hospital Really Talks to You”: Socialist Legacies and Consumerism in Czech Women's Childbirth Narratives', Czech Sociological Review, 50, 6 (2014), 961-85.

16 See Hilda Scott, Women and Socialism: Experiences from Eastern Europe (London: Alison and Busby, 1976).

17 See Heitlinger, 'Czech Nursing' and Benoit and Heitlinger, 'Women's Health Care'.

18 See further Barbara Havelková, 'The Three Stages of Gender in Law', in Hana Havelková and Libora Oates-Indruchová, eds., The Politics of Gender Culture under State Socialism. An Expropriated Voice (London: Routledge, 2014), 31-56. See also Steven Saxonberg, Hana Hašková and Jiři Mudrák, The Development of Czech Childcare Policies (Prague, Knižnice Sociologické Aktuality, 2012).

19 For an early, detailed discussion of these issues, see Scott, Women and Socialism. See also Saxonberg et al, Development.

20 Hana Havelková and Libora Oates-Indruchová, 'Expropriated Voice: Transformation of Gender Culture under State Socialism: Czech Society, 1948-89', in Hana Havelková and Libora Oates-Indruchová, eds., The Politics of Gender Culture under State Socialism. An Expropriated Voice (London, Routledge, 2014), 3-27. 
with the Prague Spring, the post-1968 government also endorsed a privatised form of citizenship focused on consumption, leisure and family life. ${ }^{21}$ Official state policies and dissident representations alike promulgated a conservative, 'petit-bourgeois' model of the family which biologised gender difference as 'down to nature', with the effect that 'gender hegemony was created and sustained by official and alternative culture alike'. ${ }^{22}$ This hegemony remained in place after socialism as former dissidents assumed leading political roles. Maternalist and pronatalist policies were reinforced, not only to support the birth rate but also as a means of managing unemployment anticipated to result from economic reform. ${ }^{23}$ The relevance of so-called Western feminism and its applicability to the post-socialist Czech context was debated, with some Czech sociologists claiming that their commitment to motherhood and family led 'Czech women' to reject feminist politics and perspectives. ${ }^{24}$

\section{Institutional Care Versus Care in the Home}

These shifts in official stance and popular perceptions of women's role in public and private life can be traced through historical and contemporary discourses about public care services and institutions. During the socialist period much attention was given to nurseries providing care for children under three years old. Public nurseries had existed in the territory of Czechoslovakia since the nineteenth century but were expanded in the early socialist period to accommodate the shift work of employees of firms in continual operation. During the 1950s Czech psychologists such as Zdeněk Matějček investigated the personal development of children in public nurseries and raised concerns about the emotional deprivation children suffered as a result of long periods of separation (often the entire working week, whilst parents worked long shifts in industry). The film Children Without Love (Détí bez lásky) became internationally known for its stark depiction of institutionalised children in Czechoslovakia. Matějček did not in fact argue that all nurseries were bad for children, but his work was misused by popular psychologists as evidence of the intrinsic harmfulness of any nursery care of children under three, thereby supporting the conservative, maternalist, pronatalist policy agenda of the late socialist and early post-socialist periods. ${ }^{25}$ In the later socialist period investment in maternity benefits was prioritised over public child care, as various experts supported the view that women were 'naturally' better suited to caring for dependent family members. For example, in the mid-1980s a prominent paediatrician argued that only 'female characteristics' and 'what is specific to the female in her biological role' could 'provide the child with all his or her needs'. ${ }^{26}$

After socialism, the quality of care in public institutions such as hospitals, old people's homes, children's homes and the like became a perennial topic of public concern and debate. Reform minded care professionals and newly forming pressure groups focused public attention on abusive and neglectful conditions within old people's homes, children's homes, residential institutions for the mentally ill and physically disabled. ${ }^{27}$ Campaigns for alternative approaches to care gained ground as major

\footnotetext{
21 Bren, 'The Greengrocer', 173-6.

22 See further Havelková and Oates-Indruchová, 'Expropriated', 15.

23 Jacqui True, Gender, Globalization, and Postsocialism: The Czech Republic After Communism (New York: Columbia University Press, 2003).

24 For further discussion of the debate on feminism in the Czech context, see Havelková and Oates-Indruchová, 'Expropriated', as well as Saxonberg et al, Development, 16.

25 A detailed discussion of these issues is provided by Saxonberg et al, Development.

26 Saxonberg et al, Development, 32.

27 See for instance Oldřich Matoušek, Ústavní Péče [Institutional Care] (Prague: Sociologické Nakladatelství, 1999); Jana Hrdá, 'Péče v Rodině, Osobní Asistence a Asistenční Služby v Zakoně o Sociální Pomoci', [Care in the Family, Personal Assistance and Assistant Services in the Social Support Law], in Pečující Rodina, a Co Dál? Sborník Přednašek z Konference Praha [A Caring Family, and What Else? Anthology of Presentations from the 1998 Conference], (Prague: Ministry of Health, Czech Republic, 1998); David Kocman, 'Quality Matters: Re-formatting the Boundaries of Care in Czech Social Care Policy', Ph.D. thesis, University of Kent, UK, 2013; Barbara H. Vann and Jan Šiška, 'From 'Cage Beds' to Inclusion: The Long Road for Individuals with Intellectual Disability in the Czech Republic', Disability and Society, 21, 5 (2006), 425-39.
} 
reorganisations of health and social care systems took shape. ${ }^{28}$ These developments were prefigured by the earlier debates and policy direction around public nurseries. As in the 1960s, in the 1990s one of the key solutions proffered to eliminate the problem of impersonal conditions in care institutions was for more care to be provided by women 'in the home'. A conference in Prague in 1998, for instance, which brought together Czech activists and practitioners from health and social care services, amongst them many advocates of de-institutionalisation, was entitled 'A Caring Family, and What Else?' (Pecující rodina, a co dál?). In the course of their discussions, delegates largely took it for granted that 'the (Czech) family' was indeed 'caring'. Dialogue explored how the state could better support families in this core function. In the opening speech, the convenor proposed a system of financial allowances to enable women to give up paid employment to care for disabled or infirm family members at home. The possibility of men taking this route was not considered or suggested. ${ }^{29}$ This contrast between 'warm' maternal nurture and 'cold' institutional care was further mobilised in the development of hospital volunteering programmes, as the following sections explore.

\section{Civil Society and the Humanisation of Health Care}

In the 1990s two conditions shaped and promoted the emergence of hospital volunteering. The first was the major structural reforms to health provision in the early 1990s, which gave hospital directors greater autonomy and clearer incentives to develop volunteering programmes as part of patient care. The second was the civil society agenda and the proliferation of non-governmental organisations (NGOs) seeking greater involvement in health and social care provision.

From the early 1990s onwards major structural reforms of the national health system were approved by the new post-socialist government. The aim was to decentralise the provision of health services and funding, introduce principles of competition between service providers and give patients more 'choice' between them. ${ }^{30}$ One result was that hospital directors and senior health professionals were incentivised to produce positive publicity for their institutions within a competitive health market. The need for this was apparent at a time when practices within hospitals, like other care institutions, were subject to new scrutiny and open criticism from academics, activists and other interest groups. In the popular textbook Institutional Care (Ustavní Péče) published in 1999, for instance, social work scholar Oldřich Matoušek mounted a strong critique of the socialist system of mass care institutions and the depersonalised, authoritarian, inhumane practices within them. He further claimed that, 'amongst the caring professions, medicine has the highest social status . . but at the same time it is probably the most conservative amongst them, clinging most strongly to the illusions of institutionalisation'. ${ }^{31}$ Responding to such critiques within a context of structural reform, hospital managers and health professionals showed new interest in developing provision aimed at enhancing the social and psychological wellbeing of long-term, hospitalised patients. Hospital volunteering began as health managers began to collaborate with activists and organisations promoting civil society.

Already an important concept and reference point for dissident opposition to socialism in the 1980s, civil society became a major social, economic and political project during the 1990s, supported by new funding flowing into the region from Western European and North American donor organisations. ${ }^{32}$ Although volunteering per se has a long history in the Czech context and existed throughout

\footnotetext{
28 See Inglot, Welfare States, 195-226, for a discussion of health reforms in the 1990s. See Kocman 'Quality Matters' for a discussion of social care reforms. Further discussion is provided in Read, 'Images of Care'.

29 Pečující Rodina, a Co Dál? Sborník Přednašek z Konference Praha [A Caring Family, and What Else? Anthology of Presentations from the 1998 Conference], (Prague: Ministry of Health, Czech Republic, 1998).

30 Kocman 'Quality Matters'; Read, 'Images of Care'.

31 Matoušek, Ústavní Péče, 74.

32 Chris Hann, 'Introduction: Political Society and Civil Anthropology' in Chris Hann and Elizabeth Dunn, eds., Civil Society: Challenging Western Models (London: Routledge, 1996), 1-26; Julie Hemment, Empowering Women in Russia: Activism, Aid and NGOs (Bloomington, Indiana: Indiana University Press, 2007); Steven Sampson, 'The Social Life of Projects. Importing Civil Society to Albania', in Chris Hann and Elizabeth Dunn, eds., Civil Society: Challenging
} 
the socialist period, volunteering in hospitals was something new. Financial investment from a variety of global charities and donor organisations had played a key role in initiating the earliest hospital volunteering projects in the late 1990s. For example, the National Volunteer Centre, based in Prague, was founded as a non-profit by two psychotherapists in the mid-1990s with funding from George Soros's Open Society Foundation and the US-based Big Brother, Big Sisters Foundation. This centre became highly active in enabling hospitals and care homes around the country to establish volunteer programmes from the late 1990s, through running a registration scheme as well as regular conferences, projects and events. Similarly, the US non-profit humanitarian organisation, Adventist Development and Relief Agency (ADRA) first began to be active in the Czech context in 1992, and at the time of my fieldwork ran ten volunteer centres in various Czech cities, many of which coordinated programmes based in hospitals and care homes. As the number of hospital volunteer programmes grew through the early to mid 2000s, they were increasingly funded through grants from national bodies (for example, the Ministry of Health), regional or city authorities and hospitals. These programmes were managed by volunteer coordinators responsible for recruiting, training and supervising volunteers for the hospital, liaising with hospital staff to link volunteers to wards where there was demand for them and securing external funding to run projects or expand their range of activities. $^{33}$

Although working in different sites across the country, volunteer coordinators at different hospitals often knew each other personally and operated within a common professional field of regular training events, conferences and expert knowledge. They shared a view of volunteering as an activity emanating from individual morality and good will. This reflected the prevalent discourse of civil society in the region more generally, which tended to take a negative view of the state. ${ }^{34}$ They dismissed volunteer activities which had been coordinated by state agencies during the socialist period as bogus forms of public participation which had been more or less obligatory and were therefore not genuine. By contrast, authentic volunteering reflected the personal altruism of the individual volunteer; 'not just good will, but free will', as one coordinator put it. Hospital volunteering was promoted as the 'humanisation of healthcare' (humanizace zdravotnictvi) - as a distinctively social and emotional form of patient care which complemented but did not replace the 'scientific' work of medical professionals. Volunteers were tasked with engaging patients in range of social activities, typically company and conversation, listening, reading, playing board or card games, light rehabilitative exercise, reminiscence or arts and crafts activities. This was caring 'with the heart', and the symbol of the heart was often used in the logos of different volunteer centres, conveying volunteering as the practice of empathy and compassion (as opposed to medical detachment). Heart imagery invoked a secularised variant of the Christian moral obligation to help thy neighbour and sometimes reflected the involvement of religious organisations in volunteering programmes. ${ }^{35}$ Explaining why volunteering was a good thing, one of the volunteer centre coordinators told me,

It is wonderful when people help each other and they don't want anything for it. It is an expression of humanity, and proof that it is natural and normal.... This way of thinking is natural and normal in the family, but I think it should also be natural in relation to other people. I think it is really fantastic that here in Prague people want to visit strangers in hospital. ... Coming to visit ill patients in an ugly old hospital . . it's really admirable. ${ }^{36}$

Western Models (London: Routledge, 1996), 121-42; Janine R. Wedel, Collision and Collusion: The Strange Case of Western Aid to Eastern Europe (New York: Palgrave, 2001).

33 See further Read, 'Images of Care'.

34 See Hann, 'Introduction: Political Society'; Hemment, 'Empowering'.

35 Cited in Andrea Muehlebach, The Moral Neoliberal: Welfare and Citizenship in Italy (Chicago: University of Chicago Press, 2012).

36 Original interview conducted in Czech and translated to English by author. Original quotation: 'Protože to je krásný, když lidi si navzájem pomáhají a nic za to nechtějí. Protože mi to přijde jako výraz lidskosti, jako důkaz toho, že to je přirozený, že to je normální. .. . Tahle myšlenka-, ono je to třeba přirozený v rámci rodiny, ale podle mě by to mělo být přirozené i 
This way of framing volunteering appealed to hospital managers wishing to develop new forms of non-medical care, not least because what was potentially on offer was relatively cheap to provide. As the deputy director of one hospital explained to me, the cost of hiring play therapists for in-patient children on her hospital's neurology ward was considered too expensive, whereas the cost of hiring two paid volunteer coordinators to support a programme of potentially hundreds of volunteers was deemed good value for money. Couched within the discourse of civil society, volunteers' care avoided association with mere unpaid labour, signalling instead a hospital's dedication to improving patient care and enabling new, democratic forms of public participation.

\section{Hospital Volunteering as Maternalism}

The hospital volunteer programmes at the focus of my ethnographic fieldwork in Prague, Ustí-nad-Labem and Ostrava varied in their organisational arrangement and numbers of volunteers. In Prague and Ústí-nad-Labem, volunteer coordinators were employed by the hospital and ran volunteer centres and programmes within them. In Ostrava the coordinator worked for a charity (ADRA) and ran volunteer programmes in two separate hospitals. Prague had seventy registered and active volunteers, Ostrava had eighty (across two hospitals) and Ústí-nad-Labem had thirty. Volunteers were expected to volunteer at least once per week, for around one to two hours, and to attend volunteer supervision sessions around once per month. The turnover of volunteers was quite high across all three sites, particularly amongst students, and coordinators ran regular recruitment and training events to keep up the numbers of volunteers on their books. They also tried, in different ways, to keep track of the 'volunteer hours' worked. The 2008 annual report of the Prague volunteer centre, for example, noted that over the previous twelve months, its volunteers had contributed a total of 3,329 hours to the hospital, averaging 280 hours per month. ${ }^{37}$

In the course of caring for patients, volunteers came into regular contact with nurses on wards. Nurses' views of volunteers varied. Hospital volunteering was still a relatively new, unfamiliar phenomenon at the time of fieldwork, and some nurses were uncertain of volunteers' motivations to care without pay for people they did not know. Volunteers' contributions were intended to complement the work of paid staff rather than replace it. Thus, volunteers did not necessarily relieve nurses' workloads, especially as nurses were required to help familiarise new volunteers with routine practices on the wards and keep volunteers informed, where necessary, about the medical condition of individual patients they visited. Nonetheless, nurses usually welcomed the contribution of regular, longstanding volunteers who they knew and trusted with patients. For instance, the head nurse of a gerontology ward explained to me that there were forty patients on the ward, and two nurses to care for them over the lunch and afternoon period of the day. Serving lunch took considerable time as many patients were unable to feed themselves. She recounted how she appreciated the presence of a regular volunteer who sat and comforted a patient with dementia who was highly distressed, helping calm her by combing her hair and speaking to her gently. 'Nurses don't have time to do this', she added. The volunteer's care for this individual patient had enabled the nurses to fulfil their duty to ensure that other patients received their lunch.

Across all three field sites, volunteers clustered into two age groups seventeen to twenty-five of years old and thirty-five or older. The younger group tended to be students whilst the older group mostly worked full time, although a few volunteers were retired. The majority of volunteers had or aspired to professional jobs, such as teachers, psychologists, IT specialists, small business owners or workers in middle-level management positions within large corporations. Broadly speaking then, hospital volunteering appealed to an educated, professional middle class, but not to people economically privileged enough to not need to work for a wage. Prior personal experience of visiting or caring for a

vůči ostatním lidem . . . Ale když někdo fakt za nemocnýma lidma, do ošklivý nemocnice starý, to je úžasný. To je opravdu obdivuhodný'.

37 Dobrovolnictví v Nemocnici [Volunteering in Hospital; name of hospital removed], Výroční Zpráva 2007 [Annual Report 2007], 12-3. 
relative in hospital often provided the initial impetus for joining a volunteer programme. For example, Ana, a fifty-three year-old interpreter for a banking group, had frequently visited her mother in hospital prior to her death, and subsequently decided to volunteer at the same hospital. Pavla, a fifty-four year-old accountant, had regularly supported a female friend and her husband after his terminal cancer diagnosis. Helena, a seventeen year old student, spoke of how she got interested in volunteering whilst caring for her grandfather following his heart attack, whilst Jan, a project manager in a construction firm in his fifties, talked of how his frequent visits to his young nephew suffering cancer had led him to volunteer. These kinds of encounters had led volunteers to recognise the value to patients of company and social activities which hospital staff did not provide. They were also gendered experiences which shaped the ways in which volunteers understood their relation to volunteering.

In each of my three fieldwork sites, around 90 per cent of volunteers were women. Maternalist ideas punctuated the narratives of both male and female volunteers around why hospital volunteers were mostly women, and why women were particularly suited to this work. Ana, for instance, said that,

in my situation I spent many years giving that care to my children. And now they are not there anymore so you know, there is a vacuum, and you have to fill it somehow. And it's very natural that women do it at this age, because they cared for their children for many years. Now they're gone, they don't need it anymore, but you have that, you know, the need, it's still there. ${ }^{38}$

Younger women, many of whom were studying in preparation for careers in female-dominated caring professions such as psychology, medicine, nursing and teaching, also identified such 'natural impulses'. Renata, who wished to become a doctor, said that her recent experience of volunteer training had enabled her to learn 'new things' about herself, particularly that it 'felt good' to look after people.

I'd say that men don't have the need to do it like a girl has. . . . Like, I know, that I need to help someone. Even if it is just for the good feeling this gives me. So I help someone. And I think that they [men] don't have this feeling. ... I think that women have a greater predisposition for this, and that it's normal. ${ }^{39}$

The small minority of male volunteers also used the idiom of maternalism in referring to female volunteers whilst presenting their own motivation in a different light. Jan and Vladimir, both in middle age, linked their desire to volunteer with their Catholic faith and the obligation they felt to help others who were sick or dying, whilst Michal and Vlada viewed hospital volunteering as a social activity linked to their friendship networks. By contrast, Jan said that women were more at ease with volunteering in hospitals because caring was 'in their genes', whilst Vladimir pointed to 'the mother's instinct' playing an important role in women's attraction to volunteering.

These narratives of volunteer motivation are consistent with the ways in which unwaged caring labour performed within families and households has been framed within social policies as well as official and popular representations since the late socialist period. In linking volunteering to an innate, biologically-given capacity to nurture, volunteers made the relatively new, unfamiliar social practice of working for free in a hospital recognisably familiar to themselves. This was not only apparent in volunteers' own narratives, but also in the ways in volunteer recruitment, training and supervision was organised.

Volunteer coordinators were unconcerned about the gender imbalance of volunteers on their books, similarly viewing the preponderance of women as inevitable and natural. Discussing the

\footnotetext{
38 Original interview conducted by author, in English.

39 Original interview conducted in Czech and translated to English by author. Original quotation: 'Řekla bych, že nemají potřebu tak jako ta holka. . . . Tak vím, že musím někomu pomoct. I kdyby to bylo jenom pro můj dobrý pocit. Tak někomu pomůžu. A myslím si, že oni třeba takovéhle pocity nemají jako pomáhat'.
} 
establishment of early volunteering, one activist remarked that he had always expected that it would appeal to 'housewives'. In Ústí-nad-Labem and Ostrava, coordinators actively promoted volunteering to students on health and social care courses (invariably women), by giving short lectures about volunteer programmes in their colleges. Coordinators' insistence on the volunteer subject as the freely choosing, altruistic individual went hand in hand with a pervasive presumption that volunteering would naturally appeal to women more than men and that women were more suited to it. The few male volunteers tended to be either roundly applauded by coordinators as 'exceptional' or regarded as somewhat suspect. For example, at a prospective volunteer interview, I listened as a Roma man in his thirties presented a detailed, articulate set of reasons why he wished to volunteer but failed to convince the volunteer coordinator of the sincerity of his motivation. This occurred at a point when a young Roma woman (on a nursing course) had just been accepted onto volunteer training. The intersection of gender with marginalised Roma ethnicity placed Roma men entirely beyond the pale for coordinators, even as Roma women were accepted.

In training and supervision sessions, volunteers' motivation was explored extensively in reflective individual and group exercises. Coordinators encouraged participants to understand their interest in volunteering as springing from a 'personal' need to care for others, and volunteering as an activity which would fulfil that wish and thereby bring about a sense of personal realisation. A series of selfreflective exercises encouraged trainee volunteers to 'discover' an internal desire to care for others, as well as personal qualities which would equip them to do so successfully. Thus, altruistic motivation to care for dependent patients was defined in terms which mirrored maternalism - as arising from a given set of inner needs and individual psychological make-up. This is not to say that volunteers' contribution to assisting patients, the hospital and the wider community was made invisible or unacknowledged. It was celebrated in annual social gatherings organised by coordinators to thank volunteers for their efforts, or at the beginning of supervision sessions in which the 'volunteer hours' performed in the past month were officially announced and volunteers present were explicitly thanked. The point is that the prevailing manner of framing volunteering in terms of a biologically given or 'inner' desire to care for others provided a means of dissociating it from waged caring labour, planting it firmly within the historical category of unwaged caring work.

\section{Conclusion}

Twentieth century maternalism, and its varied instantiations across European nation states, was grounded on two linked premises: first, that women were naturally, innately caring and, second, that care-giving activities justified women's entitlement to public resources. By the end of that century, entitlement for mothers as full time care givers was decidedly on the wane. Feminist scholarship has explored the concurrent reinvention of maternalist discourses in this context, in particular their accommodation to neoliberal restructuring, welfare retrenchment and social policies geared to encourage women's employment rather than unwaged care giving. This article has explored the transformation of Czech maternalisms of the mid- to late socialist and post-socialist periods, particularly their embodiment within, or distinction from, the different kinds of caring labour in which women are routinely engaged. Czech nursing care has been shaped by the ambitious modernisation of health provision undertaken within the early socialist period. As a caring profession, nursing constituted first and foremost the appropriate application of scientifically based expertise, rather than the practice of empathy and compassion. Thus, although mostly performed by women, nursing care foregrounded a nurse's knowledge and proficiency, and not her natural predisposition to be caring. I have suggested this is a legacy of state socialism's commitment not just to modernising health care but also to emancipating women through promoting their engagement in, and independence through, waged work. However, this emancipatory project was fatally compromised. Maternalist discourses emerging in the mid socialist period grounded the care mothers provide to children and other family members in the idiom of nature - in women's biology and their instinctive caring capacity. I have shown how such maternalist discourse continues to persist within public debates about institutional care 
versus 'home' care. Czech maternalism is not only a narrative about the importance of maternal nurturance, but also a largely negative commentary on public care services provided through institutions like hospitals. The critique of institutional care as cold and impersonal, originating in the socialist period and limited at the time to discussions about nursery care, gathered pace after socialism, extending to care homes, hospitals and other residential institutions. During the 1990s public care within institutional settings was at times framed as emblematic of the authoritarianism and dehumanisation of state socialism generally, and contrasted to care 'in the home' which was self-evidently superior and more 'natural'. Hospital volunteering emerged in the 1990s as a response, in part, to these public debates about institutional care, aided significantly by the availability of resources for civil society initiatives. I have argued that hospital volunteering marks a further transformation of Czech maternalist discourse, in that the unwaged 'maternalised' care provided by mostly female volunteers is uprooted from the ideological private space of the home and brought into the hospital-as-institution, supplementing the official care of waged health professionals, such as nurses. In making few demands for wages or other entitlement to public resource, volunteered care is consistent with neoliberal maternalisms elsewhere. The case discussed in this article also further affirms the adaptability and persistence of maternalist ideologies across divergent political and historical contexts.

Cite this article: Read R (2019). Caring Values and the Value of Care: Women, Maternalism and Caring Work in the Czech Republic. Contemporary European History 28, 500-511. https://doi.org/10.1017/S0960777319000122 